\title{
Application Values of Character Education in PPKn Lessons in SMP Negeri in the City of Palu
}

\author{
Gusnarib Wahab ${ }^{1}$, Fatimah Saguni ${ }^{2}$, M. Iksan Kahar ${ }^{3}$ \\ \{iain.gusnarib@gmail.com ${ }^{1}$, fatimahsaguniftik@gmail.com², m_iksankahar@iainpalu.ac.id $\left.{ }^{3}\right\}$ \\ Institut Agama Islam Negeri (IAIN) Palu ${ }^{1}$, Institut Agama Islam Negeri (IAIN) Palu², Institut \\ Agama Islam Negeri (IAIN) Palu ${ }^{3}$
}

\begin{abstract}
This research explores the implementation of the principles of character education in state senior high schools (SMP) in Palu. This research focuses on the application of Civics Education (PPKn) to teach principles of educational character. In the PPKn topic, the objective is to disclose positive things related to the creation of cultural values. This study will answer a research question: What is the description of character education implementation in PPKn subjects in Junior High Schools in the City of Palu? This study used a qualitative longitudinal study method, and the data were gathered through interviews with a school principal, PPKn teachers, and Kaili traditional leaders in Palu City who were related to learning PPKn in classrooms that contained character education values. After the data was collected, an analysis is carried out through data display, data verification, and conclusions drawing. The research found that character education at the State Junior High Schools has not been going well. The main obstacle includes curriculum guidance that is not yet clear, short learning time and no special institution that focuses on instilling predetermined character standards. The subject of PPKn includes character values that are expressed in the tales of characters and individuals that encourage teens to be followed by teenagers. The psychology of students needs to internalize faith, integrity, discipline, hard work, creativity, individuality, caring, accountability, character values by learning stories or behaviors that become the culture of life.
\end{abstract}

Keywords: Values, Character Education, Civic Education, PPKn.

\section{Introduction}

Basically, education is a deliberate attempt to improve the capacity of human capital and the empowerment of students by supporting and encouraging learning activities and instilling the values of life.This is in accordance with the Republic of Indonesia Law Number 20 of 2003 concerning the National Education System Chapter 1 Article 1 that education which is defined as a conscious and planned effort to create an atmosphere of learning and the learning process so that students actively develop their potential to have religious-spiritual power, self-control, personality, 
intelligence, noble character, and skills that are needed to live in a society and the state [1]. Professional educators are required to achieve the goals beginning from basic to tertiary education.

A successful teaching program will provide students with great encouragement to complete their developmental duties. In this regard, throughout the entire teaching process and development, every teacher should understand the personalities of their students, especially those related to childhood and adolescence in primary and secondary schools. The students need to internalize the ideals of life throughout the time to foster a full identity and dignity.

\section{Literature Review}

Education today is starting to lose its position as a mechanism that leads students to become completely human. For themselves and their culture, humans should portray themselves as problem-solvers. Empirically, this is clearly illustrated by the paradigm shift around ideals, essential truth, happiness, and social justice. Increasingly individualistic and consumeristic, human life is also expressed in unethical conduct, environmental degradation, legal oppression, rape, violent protests, anarchist activities, social tensions, religious or SARA abuse, and the use of foul language. About moral decadence. The situation, however, deteriorates when the character, ethical beliefs and cultural values of children are no longer the reference of life. This situation impacts changes in the character of children who are increasingly vulnerable due to such changes. The relationship or ties in the family, including parents and close relatives, the surrounding community, and educational institutions, are also minimal. Character building must be reaffirmed by learning and the importance of the ideals of character and wisdom in education, family and community. Changes that occur in lifestyles, including economic developments in the era of digitalization, have triggered global developments that have gradually changed people's behavior. On the other hand, the availability of human resources who have a noble and professional character in their fields is lacking and critical. Thus, education is needed to improve the standard of living of the nation's young generation in various creative and innovative aspects and fields as a preventive alternative to mitigate and reduce the causes of various problems of degradation of the nation's character itself.

The Central Curriculum Research and Development Agency of the Ministry of National Education states that character is defined as the character, morals, or personality of an individual formed from internalization (can be influenced by family, education, and the community environment). The character has various virtues that are believed and made based on points, the views that the individual believes thoughts, and actions. It is said that character building is the process of carving or sculpting a soul in such a way that it is unique, interesting, and different or can be distinguished from others [2]. Q-Anees and Hambali illustrate the characters are like a "muscle," that is, the "muscles" of the character will become flaccid if they have not been trained and will be strong and sturdy if they are often used (trained). Like a bodybuilder who continues to train to build muscle, the "muscles" of character will also be formed with training practices, eventually becoming a habit [3].

In line with Williams' opinion, Sriamin in Soedarsono [4] states The main reason for the importance of character building is because the character is the foundation that guides individual behavior. It starts from the beginning of the individual's life period and lasts throughout his life. In 
other words, basically, characters can't just be processed with an element of deliberation in a relatively short time or instant in adulthood. However, it can be said that these characters will grow and develop over time in a person's life. Such development dimensions are (1) individual social sensitivity, namely caring and involvement in the social environment. It is also not only caring but also solving and how to develop one's sympathy and empathy; (2) nurturance and care, which means protecting, providing protection for others, and maintaining good relations with others; (3) sharing, cooperation among human beings; (4) helping others to develop positive character and good morals; (5) honest attitude; (6) maintaining moral, which means that someone knows how other people respond. If the response is pleasant, it can be done; (7) self-control related to controlling one's own behavior without asking others to do so, and (8) solve various social problems and conflict resolution. The period of adolescent development is a period of development towards autonomy (individual independence). Furthermore, Yusuf and Nurihsan added that adolescents must be able to complete their developmental tasks, namely (1) accepting their physical condition and utilizing it effectively without complaining; (2) learn to achieve emotional independence; (3) achieve a guarantee of economic independence in the future; (4) selecting and preparing jobs according to their skills; (5) preparing for marriage and family life; and (6) developing the concept of intellectuality, creativity, and skills necessary for competence [5].

In line with Santrock (2007: 41), describing adolescence is the transition from childhood to adulthood. This period starts around the age of ten or twelve through to the age of eighteen or twenty. Teens begin to experience rapid physical development, including increasing height and weight and developing sexual function. During the period, individuals increasingly want to be free and seek their identity (self-identity). Their mind has become increasingly abstract, logical, and idealistic [6]. Mubarok emphasized that education is a process of development from individual character to essential wisdom, acquiring knowledge, and developing ethical character behavior. Therefore, it is essential to develop an individual's cognitive, affective, and psychomotor aspects in a balanced and sustainable manner. This is part of the highest educational value. Education's value can be used to neutralize various forms of inequality (conflict of interest) in several educational institutions [7].

In a social structure, in addition to the forms of disputes,Dugan and Maftuh describe four types of student/college student conflict: controversial, conceptual, interest, and developmental conflicts. Conflicts in a college usually arise in circumstances where: (1) the ideas or opinions of someone are not in line with other people's ideas and opinions and both try to find an agreement; (2) contradictory ideas persist in the mind of a person or when the information obtained does not match what one already knows; (3) someone with an interest in something tries to discourage someone from achieving their interest or gai [8]. The opinion is that cultural conflicts occur because of differences in national or ethnic origins. The disparities in gender, sexual orientation, class, and physical and mental abilities are triggered by social conflict. Prejudice, bigotry, abuse, and even other crimes frequently contribute to personal and institutional treatment of differences. It can be inferred from the explanation that differences of opinion and social inequalities are the cause of conflict [9].

\section{Methods}


The method is a way of working in understanding the object being studied. Researchers can choose one of the various existing research methods according to the objectives, properties, objects, nature of the science, or theory that supports the research. In research, it is the object that determines the method to be used [10]. The qualitative research describes and analyzes phenomena, events, social activities, attitudes, beliefs, perceptions, thoughts of people individually or in groups [11]. This study seeks to describe the data in words or sentences that are differentiated according to certain elements/parts to obtain conclusions. Meanwhile, Frankel and Wallen stated that qualitative research requires researchers to study natural phenomena and all their complexities [12].

Research that is carried out with a qualitative approach is currently getting more and more attention because it can describe the dynamic movement of studying a social phenomenon. This study used a longitudinal qualitative research method that emphasized the application of character education values in the PPKN subjects at senior high schools in Palu. The informants involved in this study include school principals, PPKN teachers, and Kaili traditional leaders.

The research instrument was the researcher [13]. The researcher's qualitative research position as a human instrument serves to determine the focus of research, select informants as data sources, perform data collection, assess data quality, analyze data, interpret data, and draw conclusions on the findings. Furthermore, it states that there is no other choice in qualitative research than making humans the main research instrument.

\section{Results and Discussion}

\subsection{Analysis of Character Education Integration through Learning and Socialization of Civic Education Topics.}

In several state junior high schools (SMP Negeri) in Palu City, this study was conducted.The junior high schools include SMP Negeri 1 Palu, SMP Negeri 2 Palu, SMP Negeri 3 Palu, SMP Negeri 4 Palu, SMP Negeri 5, and SMP Negeri 15 Palu City with 24 key informants and 12 helping informants. The analysis of data is the outcome of the triangulation of the interview results and the analysis of the documentation about the integration of character education, as presented in the table below:

Table 1. Recapitulation of Study Findings on PPKn Learning Incorporation of Character Education at SMP Negeri in Palu

\begin{tabular}{clcc}
\hline No & \multicolumn{1}{c}{ Indicators } & $\begin{array}{c}\text { Number of } \\
\text { Classes }\end{array}$ & $\begin{array}{c}\text { Percentage } \\
\text { (\%) }\end{array}$ \\
\hline 1 & $\begin{array}{l}\text { Planning the integration of character education in } \\
\text { learning from teachers is carried out at the time of } \\
\text { compiling the syllabus. }\end{array}$ & 1 & 12.5 \\
\hline 2 & $\begin{array}{l}\text { The format of the syllabus table specifically } \\
\text { contains the character values incorporated into the }\end{array}$ & 1 & 12.5 \\
\hline
\end{tabular}




\begin{tabular}{|c|c|c|c|}
\hline & learning process. & & \\
\hline 3 & $\begin{array}{l}\text { Assessment techniques included in written or oral } \\
\text { form, test and non-test evaluations }\end{array}$ & 7 & 67.5 \\
\hline 4 & $\begin{array}{l}\text { The cultural principles and attributes that will be } \\
\text { incorporated into the learning process are extracted } \\
\text { from the requirements of competence and basic } \\
\text { competencies. }\end{array}$ & 3 & 37.5 \\
\hline 5 & $\begin{array}{l}\text { The formulation of indicators for the achievement } \\
\text { of learning competencies in the study plan uses } \\
\text { operational verbs that include the cultural values of } \\
\text { the national character }\end{array}$ & 1 & 12.5 \\
\hline 6 & $\begin{array}{l}\text { The intended cultural values and national character } \\
\text { of the learning objectives are included in the } \\
\text { formulation. }\end{array}$ & 3 & 37.5 \\
\hline 7 & $\begin{array}{l}\text { A learning plan according to basic competencies, } \\
\text { learning goals, instructional materials and learning } \\
\text { tools or media is included in the learning process. }\end{array}$ & 6 & 75 \\
\hline 8 & $\begin{array}{l}\text { The structure of learning activities is established in } \\
\text { an active, creative, effective and fun learning plan } \\
\text { which is aimed at the formulation of statements in } \\
\text { learning activities to achieve the learning } \\
\text { objectives }\end{array}$ & 6 & 75 \\
\hline 9 & $\begin{array}{l}\text { The learning strategy requires a curriculum to } \\
\text { provide } \\
\text { feedback/reinforcement/enrichment/modeling/habit } \\
\text { ude and to remedy }\end{array}$ & 7 & 87.5 \\
\hline 10 & In the lesson plan, the test format is used. & 1 & 12.5 \\
\hline
\end{tabular}

\subsection{Study of Character Education Incorporation in the Implementation Process}

The results of the research on the introduction of the incorporation of character education in PPKn learning for grades VII to IX SMP Negeri in Palu based on the learning method and the content that was presented for two hours of lessons. The characters consist of 14 types divided into the discussion (M1, M2, and M3) and teachers (M4 and M5) with the following details: (1) religious with a total score of $6(75 \%)$; (2) Honesty with a total score of $8(100 \%)$; (3) tolerance with a total score of $4(50 \%)$; (4) discipline with a total score of $8(100 \%)$; (5) hard-working with a total score of $8(100 \%)$; (6) creative with a total score of $4(50 \%)$; (7) independent with a total score of $6(75 \%)$; (8) democratic with a total score of $6(75 \%) ;(8)$ curiosity with a total score of 8 $(100 \%)$; (9) like to read with a total score of $6(75 \%)$; (11) appreciate achievements with a total score of $8(100 \%)$; (12) friendly communicative with a total score of $8(100 \%)$; (13) enviromental care with a total score of $1(12.5 \%)$; and (14) resposible with a total score of $8(100 \%)$. 


\subsection{Barriers to Integrating Character Education in Civics education}

The following details are the outcomes of interviews with PPKn subject teachers regarding the obstacles to integrating character education into learning PPKn in grade VII-IX at State Junior High Schools in Palu.

Table 2. Integration Barriers

\begin{tabular}{|c|c|c|}
\hline No & Theme & True circumstances \\
\hline 1 & $\begin{array}{l}\text { Barriers to incorporating character } \\
\text { education into learning for people }\end{array}$ & $\begin{array}{l}\text { The time allocation for Civics subjects is very short, while the } \\
\text { material load that teachers have to convey to students is very } \\
\text { tight }\end{array}$ \\
\hline 2 & $\begin{array}{l}\text { Complaints in integrating character } \\
\text { education into Civics learning }\end{array}$ & $\begin{array}{l}\text { The teacher acknowledged that because of the limitations of the } \\
\text { learning media, it was hard to carry out character education for } \\
\text { each student during class hours. The infrastructure for teaching } \\
\text { and learning is also very small. }\end{array}$ \\
\hline 3 & $\begin{array}{l}\text { Suggestions for cultural } \\
\text { national chardards and } \\
\text { implementation in schools }\end{array}$ & $\begin{array}{l}\text { The teaching load of teachers should be reduced so that } \\
\text { administrative tasks that are borne by teachers to meet } \\
\text { professional standards can be carried out, or vice versa. The } \\
\text { teaching profession's administrative duties are reduced so that } \\
\text { they can carry out character education tasks for students. }\end{array}$ \\
\hline 4 & $\begin{array}{l}\text { The opinions of teachers on character } \\
\text { learning, which are applied in subjects } \\
\text { of civic education and in all subjects at } \\
\text { junior high school level (State Junior } \\
\text { High School in Palu City). }\end{array}$ & $\begin{array}{l}\text { Both informants, both primary and supporting informants, } \\
\text { accept that to teach and train our students, character education is } \\
\text { often applied. Only the tactics, strategies, processes, and } \\
\text { materials of help are different. }\end{array}$ \\
\hline
\end{tabular}

\section{Result and Discussion}

Planning for integrating character education into Civics Education learning in state junior high schools in Palu has not been implemented optimally. The ten planning indicators can be seen, which all indicators yet to reach $100 \%$ of its implementation. In the form of assignments, teachers often apply the indicator and syllabus format comprising test and non-test evaluation techniques in the written or oral form regarding results, attitudes, and job outcomes. However in the evaluation rubric with measures of the ideal student attitudes during the lesson, some junior high schools define the type of attitude assessment in the syllabus in a learning implementation plan. Although other junior high schools did not do the same thing, most teachers admitted that measuring attitudes was difficult, so that teachers tend not to define the type of the evaluation in the lesson plan. In the meantime, only the indicators for the inclusion of other character education in the syllabus format are met. by individual schools in the city because several other schools do not revise their syllabus for years and it remains unchanged for a long period.

The indicator for the integration of character education, which is mostly carried out by teachers in the lesson plan, is intended to include programs Providing constructive reviews, 
reinforcing, enriching, exceptional, habitual and/or remedial remediesl. In the learning activities, all of these are listed, including giving independent or group assignments, reflecting, and giving homework. Whereas other metrics, such as the development of competency achievement indicators and learning targets, are written only on the basis of core competencies, which involve cognitive aspects. Some other schools only mention the characters and values to be formed without explanation with operational verbs in learning so in the learning steps, there are no tasks that represent the values or characters written.

The choice of methods of learning carried out by educators is by students' needs, the abilities they need to have, their habits, and the availability of adequate facilities and infrastructure to support the learning carried out. Meanwhile, a junior high school uses a syllabus and lesson plans made by a teacher, which cannot be analyzed by the researchers because the teacher cannot provide the syllabus and lesson plans needed. The syllabus is analyzed, and the learning activities are designed according to the specified indicators, namely student-centered learning activities where most of the learning activities are carried out by students and teachers only as learning providers.

The teachers in the classroom who carry out citizenship education integrate the character education according to the methods and strategies in the schools that they use or apply. There are five cultural values and good character that are taught, namely the importance of being honest with others, time discipline, curiosity to gain knowledge, the desire to try hard, being friendly to others and the environment, and being able to be communicative. On the other hand, environmental care value is only integrated by a teacher in learning and extra-curricular activities, such as Friday morning and Sunday morning work habits. Although in the implementation, it is developed as a form of environmental sustainability, especially for cleanliness and beauty, which is used as material for student discussions about the role of plants in protecting air pollution and reforestation according to the slogan of Palu city "Green and clean." The teachers' teaching activities within the state junior high schools can be observed straight forward when they teach religious values and present examples of raising human rights. Human life's cultural and social conditions can be used as the basis of actions to strengthening the state law that Allah has given as the nature of every individual. However through discussing learning materials, such as the importance of discipline and integrity, religious values can be established. The teacher's discussion is about social care, such as caring for the environment both for living things and the environment for inanimate objects. And it can also be developed by teaching disciplinary values, including time discipline, and training students' discipline in obeying school rules that apply in institutions, at home, and in the community. Teachers are also required to emphasize to students that it is essential to comply with the existing rules in which they live and adapt as best as possible regarding respecting others and carrying out their obligations as good citizens and religious people who tolerate one another.

Students are also taught to spread the love of peace and a high sense of brotherhood in their community life. If students can obey the correct rules, then the student's answer is correct and a relatively high score. In the discussion of character material, as explained earlier, the teachers emphasize the importance of humans who have high character values in their social environment. Where humans must obey the rules that apply in society, as cultured human beings, students must understand and obey the rules, ethics, and norms that apply in the school environment. As explained, individuals who have the highest rank in Allah's eyes are individuals who have high knowledge and morals and can be role models for others and their environment. 
The challenge for teachers to incorporate character education is the busyness of teacher responsibilities, especially for certified teachers who must fulfill 24 hours of teaching time. The overload work cause teachers to be too busy with teaching hours, which cause administrative tasks cannot be implemented properly. For example, lesson plans and designing an attitude assessment model that suits student needs, revising learning tools are often ignored by the teachers. The teachers therefore recommend that the local government education agencies minimize the teaching load of teachers so that other administrative tasks can be undertaken by teachers. Teachers find it difficult to observe students' attitudes one by one in a short period of time during a civics education meeting. The most concern of the teachers is the unavailability of learning facilities and the lack of teaching media.

In the end, the development of students' character must be observed gradually and continuously. This is based on the importance of complying with the rules and ethics in school. One step to take is to divide the students into small groups and observe each meeting's students' character. Moreover, record any developments found and evaluate them, hoping that there will be feedback after learning. The teacher can also make attitude indicators that will be assessed by observing student performance during learning. When one or more students show an indicator, the teacher can immediately mark the students' effective scores. This can motivate them to be more active in learning and obtaining knowledge to develop their character.

\section{Conclusion}

Training in civics involves character ideals expressed in the actions and stories of community leaders, ulama, and unique individuals that inspire youth and deserve to be emulated as central figures by the younger generation. In particular, in order to stimulate and empower self-concept development, junior high school students in Palu City need to internalize life values in a cultural, psychological view. In learning cultural stories (habits), which are then translated into culture, the strong character's actions can be constructed by constructing the values of life. Via imaginative, appealing and pleasing techniques to improve and inspire character education, character principles are automatically incorporated into applied learning design applications.

\section{References}

[1] Depdiknas, Undang-Undang RI Nomor 20 Tahun 2003 tentang Sistem Pendidikan Nasional. Jakarta: PN. Balai Pustaka, 2001.

[2] Kemendiknas, Pengembangan Pendidikan Budaya dan Karakter Tokohremaja: Pedoman Sekolah. Jakarta: Puskur, 2010.

[3] Q-Anees dan Adang Hambali, Pendidikan Karakter Berbasis Al-Quran. Bandung: Simbiosa Rekatama Media, 2009.

[4] S. Soedarsono, Karakter Mengantar Tokoh remaja dari GelapMenuju Terang. Jakarta: Elex Media Komputindo, 2010.

[5] S. dan A. J. N. Yusuf, Landasan Bimbingan dan Konseling. Bandung: Remaja Rosdakarya, 2005.

[6] John W. Santrock, Perkembangan Anak, Jilid I Ed. Jakarta: PT. Erlangga, 2007.

[7] Mubarok, Membumikan Pendidikan Nilai: Mengumpulkan yang Terserak,Menyambung yang Terputus, dan Menyatukan yang Tercerai. Bandung: Alfabeta, 2008. 
[8] B. Maftuh, Pendidikan Resolusi Konflik. Bandung: CV Yasindo Multi Aspek, 2008.

[9] R. . Crawford, D. \& Bodine, Conflict Resolution Education, A Guide to Implementing Programs in School, Youth-Serving Organizations, and Community and Juvenile Justice Settings. 1996.

[10] Koentjaraningrat, Metode-Metode Penelitian Masyarakat. Jakarta: Gramedia, 1977.

[11] N. S. Sukmadinata, Metode Penelitian Pendidikan. Bandung: Remaja Rosdakarya dan Pascasarjana UPI, 2010.

[12] J. R. dan N. E. W. Fraenkel, How to Design and Evaluate Research in Education. New York: McGraw Hill, 2007.

[13] Sugiyono, Metode Penelitian Pendidikan: PendekatanKuantitatif, Kualitatif, dan R\&D. Bandung: Alfabeta, 2010. 